\title{
Study to improve the effective use of water in the Stompdrift-Kamanassie water scheme in the Oudtshoorn area in the Western Cape Province of South Africa
}

\author{
A. S. Roux \\ Department of Agriculture, Western Cape, South Africa
}

\begin{abstract}
The Stompdrift and Kamanassie Irrigation Scheme provides water for 13513 ha in the Klein Karoo region of the Western Cape Province of South Africa. Water losses are high in the unlined earth canals, which cover more than $50 \%$ of the total length. The two dams can on average supply 22 million cubic meters per annum $\left(\mathrm{Mm}^{3} / \mathrm{a}\right)$ of the total allocation of $28 \mathrm{Mm}^{3} / \mathrm{a}$. The fully allocated quantities of water are supplied erratically, with only a fraction of the allocations supplied in some years, with the result that about $40 \%$ of the land is irrigated in most years.

Agriculture is the backbone of the economy of the whole region and the socio-economic circumstances of the population, especially the historically disadvantaged individuals, who rely heavily on agriculture. It is thus essential that the available water should be optimally utilised for the benefit of all.

Several studies in the past could not find an economical solution to the problem and a new study was commissioned to investigate water usage and more beneficial uses. The economic feasibility of developing sources of additional water was reviewed in terms of the current economic conditions.

The improved efficiency of water use, the possible augmentation of water resources, the improved management of the water scheme and the possible effects it can have on poverty alleviation in the area, are discussed.
\end{abstract}

Keywords: water use efficiency, best management practices, irrigation, plant water requirements, water conservation, agriculture. 


\section{Introduction}

The Stompdrift-Kamanassie Irrigation Scheme is situated in the valley of the Olifants River near the town of Oudtshoorn (see Figure 1). The main sources of irrigation water for the scheme are the Stompdrift and Kamanassie Dams, which were constructed solely for the purpose of providing water for the scheme.

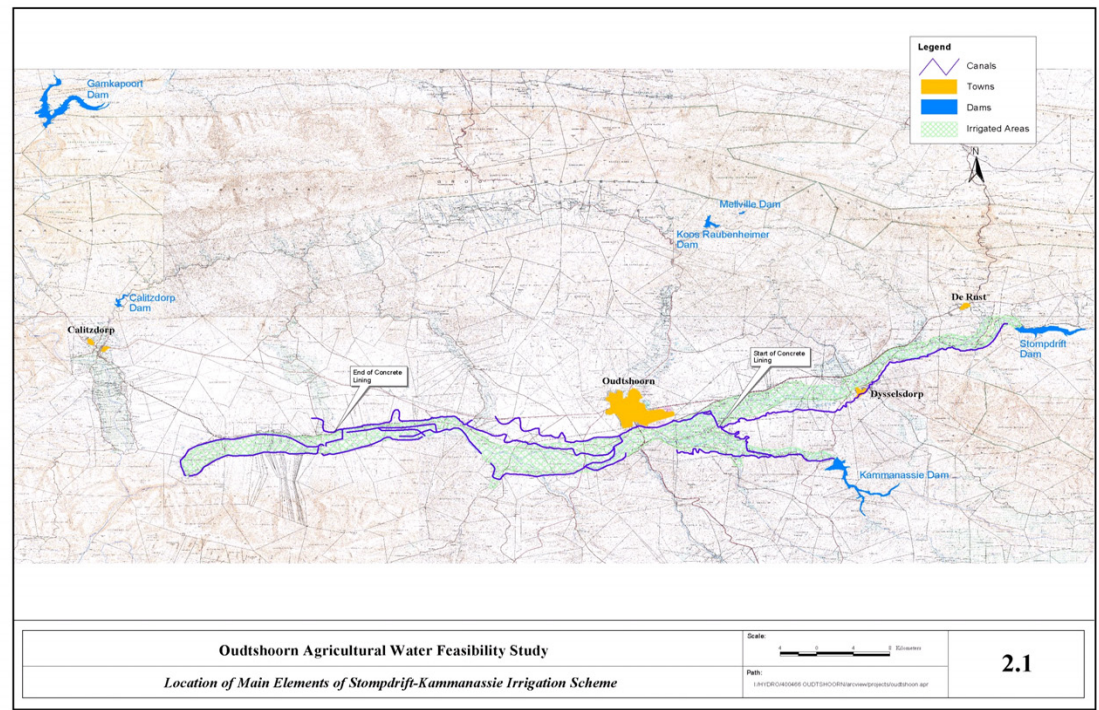

Figure 1: The Stompdrift-Kamanassie irrigation scheme.

The scheme consists of 13513 ha of irrigated land that extends along the river banks for some $105 \mathrm{~km}$ downstream of the Stompdrift Dam and $18 \mathrm{~km}$ downstream of the Kamanassie Dam, to its confluence with the Olifants River. Water is conveyed to the irrigated lands by means of a system of canals, which consists of main canals, smaller distribution canals and smaller on-farm furrows. The main canals have a combined length of $137 \mathrm{~km}$. The total length of on-farm furrows is estimated to be in excess of $100 \mathrm{~km}$.

The Kamanassie Dam and most of the canals were constructed between 1919 and 1923. The scheme was extended by the construction of the Stompdrift Dam and Canal in 1963. Since then, some unlined sections of the main canals have been lined with concrete with the result that about $64 \mathrm{~km}$ of the $105 \mathrm{~km}$ length of main canals are now concrete lined.

\section{Approach to the study}

After completion of an Inception Phase, the study was carried out in three further phases, the purposes of which were: 
Phase 1: to gain a full understanding of availability and utilisation of the water in the two dams, and to assess options for restoring and augmenting their yields or the supply of water.

$>$ Phase 2: to determine how effectively the water released from the dams is utilised, both in terms of losses and in terms of crop production, and to suggest improvements.

Phase 3: to evaluate the socio-economic implications of the various options identified in Phases 1 and 2, and to make recommendations on those that are most effective.

\section{Irrigation quotas and availability of water}

The irrigated area is divided into four zones, each with a different irrigation quota, as indicated in Table 1 below:

Table 1: $\quad$ Irrigation zones, irrigation quotas and areas.

\begin{tabular}{|c|c|c|}
\hline Zone & Scheduled area (ha) & Irrigation quota (mm/ha/a) \\
\hline A & 235 & 530 \\
\hline B & 2403 & 263 \\
\hline C & 9500 & 150 \\
\hline $\begin{array}{c}\text { Kamanassie } \\
\text { Servitude area }\end{array}$ & 1375 & 365 \\
\hline Total area & 13513 & \\
\hline
\end{tabular}

It can be seen from the above that the quotas for Zones B and $\mathrm{C}$ are far less than those for Zone A. The reason for this is when the quotas were derived, it was assumed that irrigators further downstream would be able to abstract sufficient water from flow contributed by the tributaries of the Olifants River downstream of the dam to make up the difference. This is not the case in practice because most of the available water is used for irrigation in the tributary catchments before it reaches the main channel of the Olifants River. Consequently, there is normally very little flow in the Olifants River downstream of the dams, and what little flow there is becomes too saline to be used for irrigation, due to the geological conditions.

To obtain maximum yield from the 13513 ha with the present mix of crops (98\% alfalpha and $2 \%$ higher value crops), a reliable water supply of $187 \mathrm{Mm}^{3} / \mathrm{a}$ would be required. It is estimated that the average quantity of water released from the two dams is only $22 \mathrm{Mm}^{3} / \mathrm{a}$, with the actual average quantity supplied at field edge is only $19 \mathrm{Mm}^{3} / \mathrm{a}$. Therefore, on average, there is a shortfall of $168 \mathrm{Mm}^{3} / \mathrm{a}$. It appears that, as a consequence of the shortage of water, only about $40 \%$ of the land scheduled under the scheme is irrigated in most years.

Higher value crops such as wine grapes, stone fruit and vegetables grown for seed, for which the soils and climate are suitable, require less water than alfalpha does, but at a higher assurance of supply. If water could be provided at high enough assurance for high value crops to be grown on the whole 13513 ha 
scheduled under the scheme, the field edge water requirements would decrease from the present $187 \mathrm{Mm}^{3} / \mathrm{a}$ to between $60 \mathrm{Mm}^{3} / \mathrm{a}$ and $80 \mathrm{Mm}^{3} / \mathrm{a}$, depending on the crop mix.

\section{The economy of the Oudtshoorn area}

The study highlighted the following aspects:

$>$ The economy of the Oudtshoorn area is based on agriculture with some contribution from the tourism industry, mainly the world renowned Cango Caves.

$>$ There is a high level of unemployment and associated poverty and some 30000 new jobs are required to alleviate this situation.

$>$ The potential of agriculture to contribute to employment exceeds the potential of the non-agricultural sectors. As the Stompdrift-Kamanassie Irrigation Scheme contains about $40 \%$ of the irrigated land in the area, a substantial increase in the output of the scheme would be expected to significantly increase employment opportunities in the area.

\section{Possible ways of increasing the output of the scheme}

Possibilities for increasing the output of the scheme are:

\subsection{Increasing the yields of the Stompdrift and Kamanassie Dams by eliminating any unlawful upstream water use}

It is estimated that agricultural development in the catchments of Stompdrift and Kamanassie Dams has reduced the average annual natural inflow to the dams by about $45 \mathrm{Mm}^{3} / \mathrm{a}$, or $41 \%$. Most of this development occurred before 1992, where after additional water use was severely restricted by law, with only a 5\% increase in the storage capacity of farm dams in the catchment of Kamanassie Dam since 1992. This dams only had a further reduction of $0,1 \mathrm{Mm}^{3} / \mathrm{a}$ in the inflow into the dam.

\subsection{Increasing the quantity of water available for irrigation by developing water supply augmentation schemes}

Possible augmentation schemes in the Olifants River catchment using surface water resources could only provide quantities of water that are negligible in comparison to the shortfall in optimum water requirements of $168 \mathrm{Mm}^{3} / \mathrm{a}$. Furthermore, the relatively small quantity of water that could be provided is needed either to meet ecological flow requirements or to meet urban requirements. Therefore, it is concluded that there is no significant potential within the Olifants River Catchment to augment supplies to the StompdriftKamanassie Irrigation Scheme from surface water.

The raising of the existing Gamkapoort Dam on the Gamka River might make an additional quantity of about $7 \mathrm{Mm}^{3} / \mathrm{a}$ of water available which could be used 
to supplement supplies to Zone C at a unit reference value (URV) of R1, 30/ $\mathrm{m}^{3}$. (URVs are an indication of the cost of water from a scheme). However, the existing uncertainties about the reliability of the hydrology, the environmental water requirements downstream of the dam, the needs of other stakeholders for the water supplied from the dam, and the economic viability of the scheme need to be resolved.

The development of local groundwater resources are expected to yield about $70 \mathrm{Mm}^{3} / \mathrm{a}$, but this need to be confirmed by further investigations. The URVs for groundwater schemes are estimated to range from $\mathrm{R} 0,62 / \mathrm{m}^{3}$ to $\mathrm{R} 2,58 / \mathrm{m}^{3}$.

\subsection{Reducing canal conveyance losses to make more water available at the field edge}

Based on the present average quantity $\left(22 \mathrm{Mm}^{3} / \mathrm{a}\right)$ of water released from the dams into the canals, water losses in the canals are estimated to be $4,5 \mathrm{Mm}^{3} / \mathrm{a}$. The estimate of losses is based on published data on canal losses elsewhere, and need to be verified by physical measurements of canal losses. Based on the above estimate it has been found that an average quantity of water of $2 \mathrm{Mm}^{3} / \mathrm{a}$ would be saved at a URV of R6,87/ $\mathrm{m}^{3}$ if the main canals were fully sealed and concrete lined, while $2,8 \mathrm{Mm}^{3} / \mathrm{a}$ could be saved at a URV of $\mathrm{R} 9,78 / \mathrm{m}^{3}$ if they were replaced with pipelines. See Table 2 below.

\subsection{Improving the efficiency of irrigation methods so as to obtain increased yields of crops from the same quantities of water at the field edge}

The most practical way of improving the efficiency of irrigation practices appears to be to level, by means of laser controlled methods, the lands that are flood irrigated. This has been shown on those lands where it has already been implemented to increase the efficiency of flood irrigation from $60 \%$ or lower to about $80 \%$. The estimated average saving in water if this were done throughout the scheme is $4,4 \mathrm{Mm}^{3} / \mathrm{a}$ at a URV of $\mathrm{R} 0,60 / \mathrm{m}^{3}$. See Table 2 below.

\subsection{Using the available water to produce higher value crops on reduced areas of irrigated lands}

Using the available water to produce higher value crops than alfalfa would drastically reduce the area of land irrigated because, even though crops of this type may require less water than alfalfa does to produce optimum yields, the water is required at a considerably higher assurance of supply because the crops are less tolerant of a lack of water than alfalfa is. It would also be necessary to retain water in the dams at the end of an irrigation season to ensure that there would be sufficient water for the next season if the winter rains were poor. This would result in higher evaporation losses.

If all crops were irrigated so as to meet optimum water requirements and the areas of higher value crops remained as at present, the area of alfalfa grown would reduce to the extent that the total area of land irrigated would be $20 \%$ of the total scheduled area. In this scenario the higher value crops would receive 
water at high assurance and the alfalfa would receive water at the current low assurance. The higher value crops would make up approximately $10 \%$ of the total area irrigated.

Unless the available water supply was increased significantly, increasing the area of high value crops would further reduce the total area irrigated, and a major reduction in irrigated area would be caused by a policy of irrigating the crops to provide optimum yields instead of the sub-optimum yields that are obtained from the bigger areas of land that are irrigated at present. Whilst it was shown by a financial and economic analysis that such a policy would be likely to benefit the economy of the Oudtshoorn area in general, it would severely disrupt the social structure of the farming community.

Table 2: $\quad$ Potential for water saving.

\begin{tabular}{|l|c|c|c|}
\hline Description & $\begin{array}{c}\text { Capital } \\
\text { cost } \\
(\mathrm{R} \\
\text { million })\end{array}$ & $\begin{array}{c}\text { Average } \\
\text { quantity of } \\
\text { water saved } \\
\left(\mathrm{Mm}^{3} / \mathrm{a}\right)\end{array}$ & $\begin{array}{c}\mathrm{URV} \\
\left(\mathrm{R} / \mathrm{m}^{3}\right)\end{array}$ \\
\hline Fully concrete lining all main canals & 206 & 2,0 & $\mathrm{R} 6,87$ \\
\hline Pipelines in place of main canals & 412 & 2,8 & $\mathrm{R} 9,78$ \\
\hline Laser levelling of lands & 40 & 4,4 & $\mathrm{R} 0,60$ \\
\hline
\end{tabular}

\section{Results of the financial and economic analyses}

The potential benefits of the possibilities, listed in Section 5 above, for increasing the output of the scheme were compared to the status quo by means of financial and economic analyses of different scenarios of representative agricultural practices that could be implemented on the scheme. The findings may be summarised as follows:

$>$ Levelling by laser controlled methods of cultivated lands that are flood irrigated shows significant financial benefits in comparison to conventional levelling.

$>$ Using the presently available irrigation water supply, the best financial returns from the scheme could be obtained by concentrating the water on an area of land of about $20 \%$ of the scheduled area so as to obtain optimum yields from a crop mix of $90 \%$ alfalfa and $10 \%$ higher value crops.

$>$ If this approach were adopted, none of the lands in Zone $\mathrm{C}$ would be irrigated and this would result in the loss of an estimated 155 jobs on the farms. This would probably be more than compensated for by the creation of a greater number of other jobs, spread amongst all sectors of the local economy, as a result of the extra income generated on the remaining irrigated farms.

$>$ If a substantially greater area of high value crops than the $10 \%$ of the total irrigated area referred to above was grown with a corresponding reduction in the area of alfalfa, the financial benefits would be less because more irrigation water would need to be provided at a high assurance, with the 
result that the annual average quantity of water supplied would be significantly reduced.

$>$ The cost of concrete lining the canals, or replacing the canals with pipelines, in order to reduce water losses, would exceed the income obtained from the additional quantity of water that would be made available. Therefore, this option for improving the efficiency of water use would not be financially viable unless the cost were heavily subsidised from a source outside the Oudtshoorn area.

\section{Conclusions}

The findings of the study lead to the following conclusions:

$>$ The shortfall in irrigation water has, to some extent, been brought about by substantial increases in water use in the catchments of Stompdrift and Kamanassie Dams and in the tributary catchments of the Olifants River downstream of the dams, since the dams were built.

$>$ The total shortfall in water at field edge with the existing crop mix of $98 \%$ alfalfa and $2 \%$ other crops is estimated to be $168 \mathrm{Mm}^{3} / \mathrm{a}$ and it is unlikely that there is sufficient water available at justifiable cost to provide the full shortfall. However, it appears that about half of this quantity of water might be available through a combination of developing groundwater resources, raising Gamkapoort Dam, and laser levelling the lands that are flood irrigated. Even this quantity of water would significantly increase the output of the scheme and, with the existing crop mix, could be expected to provide a significant number of new employment opportunities in the local economy.

$>$ If water could be supplied at a 1 in 20 year assurance, higher value crops such as vines, stone fruit, or vegetables for seed, which require less water than alfalfa does, could be grown on a large scale. The field edge water requirements for the scheme would then reduce from $187 \mathrm{Mm}^{3} / \mathrm{a}$ to between about $60 \mathrm{Mm}^{3} / \mathrm{a}$ and $80 \mathrm{Mm}^{3} / \mathrm{a}$, depending on the mix of crops.

$>$ For the water augmentation schemes to be financially viable, capital and operating costs would have to be heavily subsidised from a source outside the local economy.

$>$ The availability of increased quantities of irrigation water at an affordable cost would improve the financial situations of the farmers on the scheme and put them in a better position for entering into Agricultural Black Economic Empowerment ventures with their farm workers.

\section{Recommendations}

The recommendations arising from this study fall into three categories, namely:

$>$ Improved efficiency of water use

$>$ Augmentation of water supplies

$>$ Operation of the scheme and poverty alleviation.

The recommendations in each of these categories follow. 


\subsection{Improved efficiency of water use}

$>$ The removal of alien vegetation in the catchments of the Stompdrift and Kamanassie Dams should continue until the alien vegetation has been completely eradicated.

$>$ Laser levelling of flood irrigated lands to improve the efficiency with which the water is applied should be encouraged.

$>$ Reliable measurements of water losses from concrete lined and earth canals should be made and the feasibility of upgrading the canals so as to reduce water losses should be reviewed in the light of these measurements.

\subsection{Augmentation of water supplies}

$>$ Investigation of potential groundwater schemes should proceed, with particular emphasis on schemes that would use the Table Mountain Sandstone aquifers.

$>$ The Department of Water Affairs and Forestry should be asked to further investigate the feasibility of raising Gamkapoort Dam and supplying some of the additional yield obtained to Zone $\mathrm{C}$ of the Stompdrift-Kamanassie Irrigation Scheme.

\subsection{Operation of the scheme and poverty alleviation}

$>\quad$ If the water supply cannot be increased significantly, the possibility of using in Zone $\mathrm{B}$ the irrigation water that is allocated to Zone $\mathrm{C}$ at present should be investigated in more detail because there may be economic advantages in using the water in this way. The social impacts and ways of adequately compensating farmers and farm workers and their families who would be disadvantaged by the change should also be investigated, and the apparent potential for the change to benefit the Oudtshoorn community as a whole should be verified.

$>$ The current small-scale farmer activities should be recognised, stabilised and strengthened through actions such as assistance with laser levelling of their irrigated lands, and on-farm skills transfer, especially in matters such as farm management and financial management.

$>$ Zones A and B should be favoured as areas for new opportunities for emerging farmers because of the better water supplies in these zones.

$>$ Mechanisms should be developed to promote workable collaboration between established commercial farmers and emerging farmers so that the latter can avoid commonly made mistakes and learn from successes achieved.

$>$ The job creation potential of tourism on farms should be acknowledged and explored.

$>$ As it is recognized that agriculture alone could not possibly generate 30000 jobs, efforts should also be made to create employment in the general local economy. 


\section{References}

[1] Bredenkamp, D B, Botha, L J, Van Tonder, G J and Van Rensburg, H J. 1995. Manual on quantitative estimation of Groundwater Recharge and Aquifer Storativity. Water Research Commission (WRC) Report No TT 73/95, 363 pp. \& 2 appends.

[2] Davis. 1993. Davis' Handbook of Applied Hydraulics. Vincent J Zipparro, Editor-in-chief, Hans Hasen, co-editor. Published by McGraw-Hill, Inc. 1993

[3] DeHayr, R and Gordon, I. 2004. Irrigation Water Quality - Salinity and Soil Structure Stability produced by the State of Queensland (Department of Natural Resources, Mines and Energy) Obtained from www.nrme.qld.gov.au/factsheets/pdf/water/w55.pdf

[4] Doorenbos, J. \& Pruitt, W.O. 1975. FAO 24. Guidelines for predicting crop water requirements.

[5] Green. 1985. Estimated Irrigation Requirements of Crops in South Africa part 1. G C Green, editor. Department of Agriculture and Water Supply, Pretoria. 1985

[6] Hewitson, B C. 2003. Developing Perturbations for Climate Change Impact Assessments. Climate System Analysis Group, Department of Environmental and Geographical Sciences, University of Cape Town, EOS, Transactions, American Geophysical Union, Vol. 84, No. 35.

[7] Koegelenberg, F.H. \& Roux, A.S. 2000. Water Conservation Campaign in Agriculture: Interim Summarized Report.

[8] Laker, M.C. 2006. Soil productivity in irrigated agriculture, with special reference to South Africa. Paper delivered at SARIA meeting, Roode Valley, Pretoria, South Africa. Southern African Irrigation Association. February 2006.

[9] McDonald, S. and Punt, C. 2004. Analysis with a social accounting matrix for the Western Cape. Department of Agriculture, Western Cape. Elsenburg.

[10] Tripp, R. 2001. Agricultural Technology Policies for Rural Development Policy Review, Volume 19. December 2001. doi:10.1111/1467-7679.00146

[11] Van Koppen, B., Namara, R., and Safilios-Rothschild, C., 2005, Reducing poverty through investments in agricultural water management. Poverty and gender issues and synthesis of sub Saharan Africa case study reports. IWMI, 2005.

[12] Visser, B. 1980. Soil Survey in Oudtshoorn Area. Department of Agriculture, Western Cape Province, Elsenburg. 1980.

[13] Umvoto. 2003. Deep Artesian Groundwater Exploration in the Greater Oudtshoorn District for Bulk Water Supply (DAGEOS). Phase B Report. 